\title{
Development of pH Independent Drug Release System for Dipyridamole
}

\author{
Adimulapu Anilkumar ${ }^{1 *}$, Talasila Eswara Gopala Krishna Murthy², Avula Prameela Rani ${ }^{3}$ \\ ${ }^{1}$ Research Scholar, School of Pharmaceutical Sciences and Technologies, JNTUK, Kakinada- 533003, Andhra Pradesh, INIDA. \\ ${ }^{2}$ Bapatla College of Pharmacy, Bapatla, Guntur, Andhra Pradesh, INDIA. \\ ${ }^{3}$ University College of Pharmaceutical Sciences, ANU, Guntur, Andhra Pradesh, INDIA.
}

\begin{abstract}
Introduction: Dipyridamole is an Anti-platelet agent exhibits release problems at higher $\mathrm{pH}$ of small intestine due to its $\mathrm{pH}$ dependent solubility and precipitation followed by interruption of drug release from dosage form. To overcome this extended release formulation was developed by using $\mathrm{pH}$ modulating agent (tartaric acid). Objective: Present study was undertaken with a view of the formulations evaluated by performing dissolution testing on developed extended released tablets. Method: development of dissolution method at different time points and USP Apparatus 1 (basket) and 2 (paddle) at rotating speeds of 50 or $100 \mathrm{rpm}$ used to evaluate the release characteristics of the formulations. Furthermore, solubility and in vitro dissolution studies of formulated tablets were performed at $\mathrm{pH}$ values of 1.2 and 5.5. Results: In this study we found increasing volume of dissolution medium $\mathrm{pH} 5.5$ phosphate buffers drug precipitation is increased. The developed dissolution method was validated according to $\mathrm{ICH}$ guidelines for various parameters such as specificity, accuracy, precision, and stability. The dissolution method was confirmed by determining the dissolution rate of extended released Dipyridamole tablets containing $\mathrm{pH}$ modulating agent. The best in vitro dissolution profile was obtained using $\mathrm{pH} 5.5$ phosphate buffer as the dissolution medium $(500 \mathrm{ml})$ stirred at $100 \mathrm{rpm}$. A comparison of the dissolution profiles in official and developed media showed significant differences based on $f 1$ and $f 2$ values. Conclusion: The developed dissolution test exhibited a higher capacity than the compendia methods in differentiating the release profiles of $\mathrm{pH}$ independent extended release tablets. It can be applied during formulation development and quality control analysis of $\mathrm{pH}$ independent extended release tablets for evaluation of the effects of $\mathrm{pH}$ modifier in dissolution medium and processing parameters.
\end{abstract}

Key words: Tartaric acid, Dissolution media, Extended release Dipyridamole Tablets.

\section{INTRODUCTION}

Dissolution testing has been a key tool during drug development process and in the marketable preparation of the formulation. ${ }^{1}$ At the formulation development process, dissolution testing is used to evaluate stability of the product consistency, and evaluate the effect of variables on the characteristics of the final drug product. ${ }^{2}$ For commercial dosage form, dissolution testing is used to confirm manufacturing and product consistency and to evaluate different process variables. ${ }^{3}$ In dissolution test development, the process should focus on assessing relevant physical and chemical properties of the API and dosage form design, because these will guide the choice of the dissolution medium and apparatus. ${ }^{4}$ Most of the drugs have $\mathrm{pH}$-dependent solubility exhibiting varying release rates with changing $\mathrm{pH}$ in the gastrointestinal tract. ${ }^{5}$ Weakly basic drugs are highly soluble in acidic $\mathrm{pH}(1-3)$ to increase the $\mathrm{pH}$ solubility, it will be decreased. It causes conversion of the more ionizable drug to a less soluble form. Therefore the diffusion rate of the drug through the matrix is reduced. This conversion into an
Submission Date: 24-11-2017; Revision Date: 22-12-2017; Accepted Date: 14-02-2018

DOI: 10.5530/ijper.52.3.43 Correspondence: Anil Kumar,

JNTUK Scholar, Department of Pharmaceutics, Vikas College of Pharmacy, Vissannapeta, Krishna, Andhra Pradesh, INDIA Phone: 91-9866529250 E-mail: anilkumar.adi@gmail. com

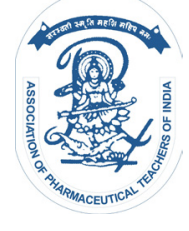

www.ijper.org 
insoluble form depends on the $\mathrm{pKa}$ value of the drug substance and the $\mathrm{pH}$ of the gastro intestinal Fluids. ${ }^{6} \mathrm{It}$ is impossible to change the $\mathrm{pH}$ of the medium; an optimized $\mathrm{pH}$ in the dosage form can be used to modulate the release rate of drugs exhibiting $\mathrm{pH}$-independent solubility and to overcome the problem of varying drug release patterns in different $\mathrm{pH}$ environments. Most widely used strategy is the inclusion of $\mathrm{pH}$ modifiers in the dosage form. This will alter the micro environmental $\mathrm{pH}$ within and in the close surrounding area of the matrix system. A buffer is a solution that can resist $\mathrm{pH}$ change upon the addition of acidic or basic substances. It is capable to neutralize small amounts of added acid or base, as a result maintaining the $\mathrm{pH}$ of the solution relatively stable. This is important for processes and reactions which require specific and stable $\mathrm{pH}$ ranges. The aim of this investigation was to assess the effect of different dissolution medium and release mechanisms of Dipyridamole Extending release matrix tablet dosage form with $\mathrm{pH}$ modulating agent. ${ }^{7}$

\section{MATERIALS AND METHODS}

Dipyridamole was received as a gift sample from R-chem pharma Pvt. Ltd., Hyderabad. Methocel K100M was purchased from Yarrow chem., Product, Mumbai. Micro crystalline cellulose (Avicel PH 101), Sodium hydroxide, Magnesium Stearate, and Talc were purchased from (S.D.Fine Chem Ltd., India), Sodium hydroxide from Merck (Darmstadt, Germany). Methanol (isocratc grade), Potassium dihydrogen phosphate (ACS grade) and Tartaric acid were purchased from Aman scientific Vijayawada.

\section{Determination of Dipyridamole drug content sample}

During dissolution testing, samples were collected at specified time intervals, and the Dipyridamole drug content was determined by UV spectroscopy at absorption maxima $283 \mathrm{~nm}^{8}$ In addition to the officially recommended at dissolution medium ( $\mathrm{pH} 1.2$, and $\mathrm{pH}$ 5.5), phosphate buffer 5.5 alone and with different volumes were used as dissolution media.

\section{Dissolution test}

Dipyridamole tablets with $\mathrm{pH}$ modulating agent was passed out using a VEEGO Scientific dissolution apparatus (8DR, INDIA). The test was performed according to pharmacopoeia specifications using Apparatus 2 (paddle method). The dissolution media employed for testing were $\mathrm{pH} 1.2, \mathrm{pH} 5.5$ phosphate buffers, Paddle rotation was set at $100 \mathrm{rpm}$. Medium temperature was set at $37 \pm 0.5^{\circ} \mathrm{C}$. Six tablets of each formulation were placed one in each vessel containing $900 \mathrm{ml}$ of the test medium. Samples $(5 \mathrm{ml})$ were withdrawn at predetermined different time points and the volume withdrawn was taken into consideration when calculating the percentage release of Dipyridamole in the remaining volume of test medium. The percentage release of Dipyridamole from formulations was determined using the UV spectroscopic method described above. The linearity of the method over the expected concentration range of $2-10 \mu \mathrm{g} / \mathrm{ml}$, which covers $20-125 \%$ of the anticipated $100 \%$ concentration (i.e., the concentration resulting from the dissolution of an $200 \mathrm{mg}$ Dipyridamole tablet in $900 \mathrm{~mL}$ of medium). ${ }^{9}$ With an average correlation coefficient of 0.9984 , the effect of paddle speed on the dissolution rate was studied at $50 \mathrm{rpm}$ (usp recommended speed) and $100 \mathrm{rpm}$ in all dissolution media. ${ }^{10}$

\section{Preparation of standard stock solution}

A stock solution of Dipyridamole was prepared by dissolving drug in methanol to obtain a concentration of $1 \mathrm{mg} / \mathrm{ml}$. Working solutions were prepared on a daily

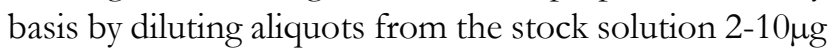
with respective dissolution media. Each solution was filtered before analysis. ${ }^{11}$

\section{Specificity}

Specificity of the dissolution method was evaluated by investigative the effect of each dissolution medium and concentration absorbance values. Each dissolution medium was evaluated without drug and with a known amount of drug, and the results were compared.

\section{Accuracy}

The percent recovery was used to determine the accuracy of the anticipated dissolution method. A solution containing $1 \mathrm{mg} / \mathrm{ml}$ was prepared in methanol. Aliquots concentration of the solution was added to the dissolution medium $(900 \mathrm{ml})$ to obtain a drug concentration in the range of $80-120 \%$ of the nominal dose. The dissolution medium was kept at $37 \pm 2{ }^{\circ} \mathrm{C}$ and stirred at $100 \mathrm{rpm}$ for $15 \mathrm{~min}$. Samples (5 ml) were withdrawn and analyzed for drug content.

Where $A$ is the absorbance of the test solution and $B$ is the absorbance of standard solution. For each sample, percent recovery was calculated in triplicate, and results are accessible in terms of mean, standard deviation, and relative standard deviation (mean $\pm \mathrm{SD}$; RSD).

\section{Precision}

The method was determined in terms of repeatability and intermediate precision. For repeatability, the dissolution test was performed simultaneously in six dissolution vessels under the same conditions, and the 
results were compared for Intermediate precision was evaluated on the basis of intraday and inter day studies. An intraday study was performed by repeating the dissolution test three times a day, and the results were compared. For the intraday study, the dissolution test was repeated on daily basis for two days under the same conditions, and results were compared for similarity. An RSD less than 5\% indicates acceptable precision of the method. Solution stability was determined at three temperatures $\left(2-8{ }^{\circ} \mathrm{C}, 24 \pm 3^{\circ} \mathrm{C}\right.$, and $\left.40 \pm 3^{\circ} \mathrm{C}\right)$ for two days. A stock solution of Dipyridamole was diluted with the respective different volumes of dissolution media to $20 \mu \mathrm{g} / \mathrm{ml}$. Each solution was divided into three portions and stored at the specified temperatures. Samples were analyzed daily for Dipyridamole content, and the percent recovery was calculated in triplicate.

\section{Dissolution Profiles by Model-Independent Method}

A model-independent approach was applied for the comparison of dissolution profiles. The dissolution profiles of the formulated Dipyridamol tablets were compared with both medium $\mathrm{pH} 1.2$ and $\mathrm{pH} 5.5$ phosphate buffer and evaluate $\mathrm{pH}$-independent release pattern of Dipyridamole from the optimized tablets .The comparison of dissolution profiles was based on the similarity factor $(f 2)$ and dissimilarity factor (f1), calculated using following equations:

$$
\begin{aligned}
& \mathrm{f} 2=50 \times \log \left\{\left[1+(1 / \mathrm{n}) \mathrm{S}_{\mathrm{t}=1}{ }^{\mathrm{n}}\left(\mathrm{R}_{\mathrm{t}}-\mathrm{T}_{\mathrm{t}}\right)^{2}\right]-0.5 \times 100\right\} \ldots \text { (1) } \\
& \mathrm{f} 1=\left\{\left[\mathrm{S}_{\mathrm{t}=1}{ }^{\mathrm{n}}\left|\mathrm{R}_{\mathrm{t}}-\mathrm{T}_{\mathrm{t}}\right|\right] /\left[\mathrm{S}_{\mathrm{t}=1}{ }^{\mathrm{n}} \mathrm{R}_{\mathrm{t}}\right]\right\} \times 100
\end{aligned}
$$

Where $\mathrm{R} t$ is the dissolution rate of $\mathrm{pH} 1.2$ at time $t$, and $\mathrm{T} t$ is the dissolution rate in $\mathrm{pH} 5.5$ at time $t$. An $f 2$ value of 50 or greater ensures sameness or equivalence of the two curves and also the performance of the two mediums.

\section{RESULTS AND DISCUSSION}

\section{Effect of pH on solubility of Dipyridamole}

Solubility plays a major role in the dissolution of a drug substance from a solid dosage form. Relationship between solubility and dissolution rate of different drug substances in various media are well established. The Solubility of Dipyridamole was carried out in different acidic and basic buffer mediums, the solubility studies was revealed Dipyridamole is a completely $\mathrm{pH}$ dependent soluble drug solubility data was shown in Table 1 . The drug maximum solubility in acidic media $0.1 \mathrm{~N} \mathrm{HCl}$, whereas increasing the $\mathrm{pH}$ of the medium solubility was decreased, and immediate lump formation of the drug was found in $\mathrm{pH}$ 6.8. Which indicates remarkable difference in drug solubility. Sink conditions occur when the

\begin{tabular}{|c|c|c|}
\hline \begin{tabular}{c} 
Table 1: Effect of pH on solubility of Dipyridamole. \\
\hline $\begin{array}{c}\text { Sample } \\
\text { Number }\end{array}$
\end{tabular} & pH dissolution medium & Solubility $(\mathrm{mg} / \mathrm{ml})$ \\
\hline 1 & 1.2 & $30 \pm 0.11$ \\
\hline 2 & 3.4 & $23 \pm 0.43$ \\
\hline 3 & 4.2 & $10.8 \pm 0.36$ \\
\hline 4 & 5.0 & $3.7 \pm 0.17$ \\
\hline 5 & 5.5 & $0.067 \pm 0.024$ \\
\hline 6 & 6.8 & $0.046 \pm 0.011$ \\
\hline 7 & 7.4 & $0.022 \pm 0.01$ \\
\hline
\end{tabular}

Values reported as mean $\pm S D(n=3)$

amount of drug that can be dissolved in the dissolution medium is three times greater than the amount of drug to be dissolved. On the basis of solubility, sink conditions can be achieved using $\mathrm{pH} 5.5$ phosphate buffer as dissolution medium. The rate of drug dissolution will be slowed by the limited solubility of the drug in that medium. ${ }^{15}$

\section{Dissolution development of Dipyridamole extended released tablets}

Dipyridamole is a $\mathrm{pH}$ dependent weakly basic Class 2 insoluble drug and is available market as 200-mg pellets. The drug release of Dipyridamole tablets found the highest solubility and lower ( $\mathrm{pH}$ 1.2), and drug precipitation was found in $\mathrm{pH} 5.5$ which would mark the effect of variables son dissolution rate. Tablet dosage form was not available in market due to $\mathrm{pH}$ dependent solubility. A novel experiment has done Dipyridamole matrix tablet $(200 \mathrm{mg}$ ) with $\mathrm{pH}$ modulating agents to create micro environmental $\mathrm{pH}$ and drug release will enhance in intestinal $\mathrm{pH}$. The inability of the recommended FDA, the $\mathrm{pH} 5.5$ as the medium for dissolution $900 \mathrm{ml}$ testing of Dipyridamole at $100 \mathrm{rpm}$. The objective of this study was the development and validation of a dissolution method for novel $\mathrm{pH}$ independent extended Dipyridamole tablets. Drug release is found completely $\mathrm{pH}$ dependent drug release. The official method is unable to drug release in $\mathrm{pH} 5.5$ phosphate buffers. A summary of the dissolution profiles obtained is presented in Table 2.

\section{Development of dissolution method test conditions}

Dissolution test conditions were selected on the basis of a selection study conducted on $\mathrm{pH}$ independent extended release tablets of Dipyridamole $(200 \mathrm{mg}$ ) using USP Apparatus 2 (paddle). The dissolution rate was determined in deferent dissolution media (pH1.2), purified water, and phosphate buffer (5.5), at deferent volumes $(100-900 \mathrm{ml})$, and at different string speeds (50 and $100 \mathrm{rpm})$.The highest dissolution rate was 
Table 2: Dissolution profile studies of Dipyridamole $\mathrm{HCl}$.

\begin{tabular}{|c|c|c|c|c|}
\hline \multirow{5}{*}{ TIME(hr) } & $\mathbf{5 0} \mathbf{~ r p m ~ i n ~ 9 0 0 m l ~ d i s s o l u t i o n ~ m e d i u m ~}$ & 100rpm in 500 $\mathbf{~ m l ~ d i s s o l u t i o n ~ m e d i u m ~}$ \\
\cline { 2 - 5 } & pH 1.2 & pH 5.5 & pH 1.2 & pH 5.5 \\
\hline 1 & $24.11 \pm 0.73$ & $2.11 \pm 0.83$ & $25.11 \pm 0.73$ & $17 \pm 0.9$ \\
\hline 2 & $36 \pm 1.12$ & $4.34 \pm 0.13$ & $38 \pm 1.12$ & $29.11 \pm 1.23$. \\
\hline 3 & $51 \pm 2.23$ & $6.14 \pm 1.28$ & $53 \pm 2.23$ & $42 \pm 2.11$ \\
\hline 4 & $62 \pm 1.23$ & $.8 .18 \pm 2.23$ & $65 \pm 1.23$ & $59 \pm 0.97$ \\
\hline 5 & $79 \pm 0.98$ & $9.88 \pm 0.63$ & $81 \pm 0.98$ & $65 \pm 1.5$ \\
\hline 6 & $85 \pm 0.83$ & $10.94 \pm 0.27$ & $89 \pm 0.83$ & $75 \pm 1.2$ \\
\hline 7 & $91 \pm 1.12$ & $12.81 \pm 0.73$ & $94 \pm 1.12$ & $85 \pm 0.89$ \\
\hline 8 & $98 \pm 0.93$ & $13.94 \pm 0.64$ & $100 \pm 0.93$ & $97 \pm 0.67$ \\
\hline
\end{tabular}

Values reported as mean $\pm S D(n=6)$

observed with the dissolution medium (pH1.2), irrespective of volume of dissolution medium. There was no difference in percentage of drug released at 50 and $100 \mathrm{rpm}$ in different volumes $(100-900 \mathrm{ml})$ of the $\mathrm{pH} 1.2$, because of its high solubility. In case of phosphate buffer ( $\mathrm{pH} 5.5)$ higher volume $(900 \mathrm{ml})$ drug was immediately precipitated due to $\mathrm{pH}$ dependent solubility of Dipyridamole. The following stages were done to develop dissolution medium.

Step-1: Drug and Dipyridamol was taken 1:1 ratio. 200mg Dipyridamole and 200mg of tartaric acid was dissolved in $1 \mathrm{ml}$ of water. We found that drug was clear solution completely soluble, further that $1 \mathrm{ml}$ drug and tartaric acid solution was transferred in $900 \mathrm{ml}$ of $\mathrm{pH}$ 5.5. Based on our investigations we found the drug was immediately precipitated in 5.5 phosphate buffer, in case of water we found clear solution precipitation was not formed, then we found drug and tartaric acid interaction occur, phosphate buffer in inhibiting the tartaric acid action.

Step-2: Dipyridamole and tartaric acid 1:1 ratio was dissolved in different volumes of dissolution medium $(100,200,300,400,500,600,700,800,900 \mathrm{ml})$ and observed up to $24 \mathrm{~h}$ in a normal room temperature. $900 \mathrm{ml}$ to $600 \mathrm{ml}$ within $10 \mathrm{~min}$, precipitation was formed; Whereas 500 , 400 and $300 \mathrm{ml}$ precipitation was formed after $15 \mathrm{~h}$. Incase 100 and $200 \mathrm{ml} 250$, precipitations was not found after $24 \mathrm{hr}$, finally we found when the phosphate buffer volume was increased, drug precipitation also increased and drug content decreased. Drug precipitation was shown in Figures 1, 2.

\section{Authorization of Dissolution method test conditions}

The $\mathrm{pH}$ independent controlled release of Dipyridamole containing tartaric acid as $\mathrm{pH}$ modulating agent were prepared, and the in vitro release study was determined in the selected dissolution medium method. Based on these results, this dissolution test method is considered

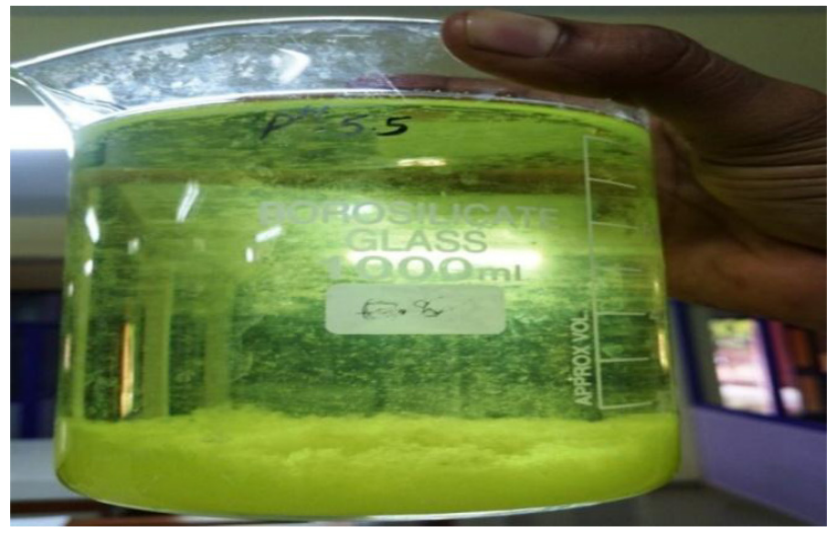

Figure 1: Precipitation of the drug in pH 5.5 dissolution medium (900ml).

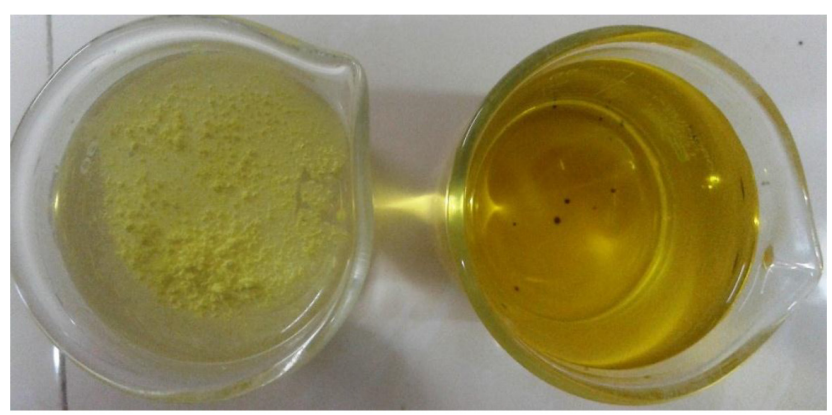

A) pH 6.8 phosphate buffer

B) pH 5.5 phosphate buffer

Figure 2: Drug was not precipitated phosphate buffer pH 5.5 (500ml volume).

to conduct dissolution test for $\mathrm{pH}$ independent extended release tablets by using $\mathrm{pH}$ modulating agents because it differentiate between products having differences in pharmaceutical attributes ( $\mathrm{pH}$ dependent solubility). $\mathrm{pH}$ independent extended released tablets exhibited almost similar dissolution profiles at the two levels of paddle speed (50 and $100 \mathrm{rpm}$ ) irrespective of dissolution volume in $\mathrm{pH} 1.2$.. On the other hand, up to $10 \%$ drug release was observed in phosphate buffer ( $\mathrm{pH}$ 5.5) due to $\mathrm{pH}$ dependent solubility, Dipyridamole is practically 
insoluble in $\mathrm{pH} 5.5$ leading to its incomplete dissolution rate. The reduce the volume of dissolution medium is usually recommended due to enhance drug release in $\mathrm{pH} 5.5$ due to reducing the interaction of tartaric acid effect on $\mathrm{pH}$ modulating agent function, in case existing official method of $900 \mathrm{ml} \mathrm{pH} 5.5$ phosphate buffer tartaric acid effect is diluting with high concentrations of phosphate buffer than drug is precipitating in this formulation for $\mathrm{pH}$ independent release tartaric acid was used as release modifier it should maintain acidic $\mathrm{pH}$ inside of the tablet to enhance the drug release in pH 5.5 phosphate buffer. Still tablet dosage form was not available in marked official dissolution data was there for pellet form this data was not possible with this novel developed dosage form. .From the study of drug release profiles, it is possible to establish dissolution test parameters that can be used as an alternative to the official dissolution test for Dipyridamole tablets, the use of $500 \mathrm{ml}$ of $\mathrm{pH} 5.5$ phosphate buffers at $37^{\circ} \mathrm{C}$ with a string rate of $100 \mathrm{rpm}$ provided complete drug, released from Dipyridamole matrix tablets. The similarity factor ( 2 ) was calculated for both the profiles, which further confirmed similarity value is 62. Developed dissolution method Drug release in different volume of dissolution medium graph was shown in Figures 3 and 4.

\section{Specificity}

The disolutio method was estimated on the basis of stability dissolution medium and dissolution medium containing deferent concentrations of Dipyridamole, while media with deferent concentrations of Dipyridomole exhibited $100 \%$ drug concentration. ${ }^{16}$

\section{Accuracy}

The method was evaluated on the basis of percent recovery. Percent recovery from 95.0 to $105.0 \%$ is recommended for the accuracy test. The mean recovery for Dipyridamole was in the range of $99.5-102.9 \%$, as show in Table 3, representing that the dissolution method is accurate.

\section{Precision}

Results for the intraday and intraday precision are concluded in Table 2 . The RSD value is less $<1 \%$ and shows that the dissolution method has been superior precision Stability: The stability of Dipyridamole in the dissolution medium purified water, $\mathrm{pH} 1.2$ and $\mathrm{pH} 5.5$ was evaluated using standards and samples. The drug content of the samples was within 98-101\% (Table 4) of the initial value over the test period (2days), and drug degradation was not observed in any of the dissolution medium, signifying stability of Dipyridamole in the dissolution medium.

\section{Table 3: Dissolution Method Validation Parameters.}

\begin{tabular}{|c|c|}
\hline Parameter & Result (Mean \pm SD; RSD \\
\hline \multicolumn{2}{|l|}{ Accuracy } \\
\hline $200 \mathrm{mg}(100 \%)$ & $100.01 \pm 0.32 ; 0.32$ \\
\hline $100 \mathrm{mg}(100 \%)$ & $100.01 \pm 0.32 ; 0.32$ \\
\hline \multicolumn{2}{|l|}{ Precision } \\
\hline \multicolumn{2}{|l|}{ Repeatability } \\
\hline Vessel $1\left(V_{1}\right)$ & $100.94 \pm 0.56$ \\
\hline Vessel 2(V2 & $99.97 \pm 0.41$ \\
\hline Vessel $3\left(V_{3}\right)$ & $98.72 \pm 0.32$ \\
\hline Vessel $4\left(V_{4}\right)$ & $100.92 \pm 0.73$ \\
\hline \multicolumn{2}{|l|}{ Intermediate precision } \\
\hline \multicolumn{2}{|l|}{ Intraday reproducibility } \\
\hline $1 \mathrm{hr}$ & $100.02 \pm 0.67$ \\
\hline $10 \mathrm{hr}$ & $99.02 \pm 0.64$ \\
\hline $24 \mathrm{hr}$ & $98.02 \pm 0.76$ \\
\hline \multicolumn{2}{|l|}{ Inter day reproducibility } \\
\hline Day 1 & $.12 \pm 0.76$ \\
\hline Day 2 & $98.02 \pm 0.76$ \\
\hline
\end{tabular}

Results are mean $\pm S . D ; R S D(n=3)$.

Dissolution medium: $p H$ 5.5 phosphate buffer, temperature: $37 \pm 2{ }^{\circ} \mathrm{C}$; paddle speed: 10orpm; medium volume: $500 \mathrm{ml}$.
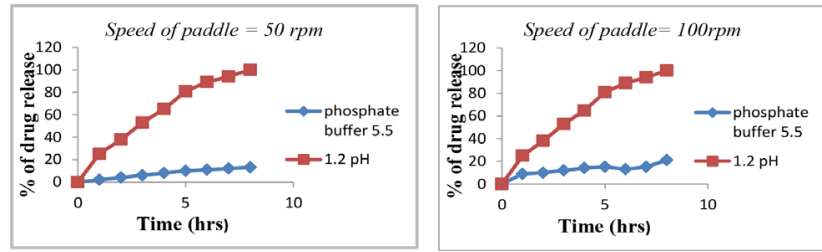

Figure 3: Release profiles of Dipyridamole from tablet determined at different paddle speeds (50 and $100 \mathrm{rpm})$ in $900 \mathrm{~mL}$ of medium.

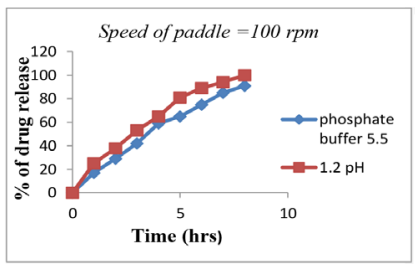

Figure 4: Release profiles of Dipyridamole from tablet determined at different paddle speeds (50 and $100 \mathrm{rpm})$ in $500 \mathrm{~mL}$ of medium. 


\begin{tabular}{|c|c|c|c|}
\hline \multirow{2}{*}{$\begin{array}{l}\text { Composition } \\
\text { of Solvent }\end{array}$} & \multicolumn{3}{|c|}{ Percent Recovery } \\
\hline & $\begin{array}{c}\text { Ambient } \\
\text { Temperature }\end{array}$ & $\begin{array}{l}\text { Refrigerator } \\
\text { Temperature }\end{array}$ & $\begin{array}{c}\text { Elevated } \\
\text { Temperature }\end{array}$ \\
\hline $\begin{array}{l}\text { Standard } \\
\text { solution }\end{array}$ & $99.88 \pm 0.53$ & $99.7 \pm 0.43$ & $99.76 \pm 0.36$ \\
\hline purified water & $100.09 \pm 0.61$ & $99.82 \pm 0.67$ & $98.63 \pm 0.60$ \\
\hline $\begin{array}{l}\mathrm{pH} 1.2 \\
\text { medium }\end{array}$ & $99.67 \pm 0.29$ & $99.69 \pm 0.28$ & $99.49 \pm 0.62$ \\
\hline $\begin{array}{c}\text { pH } 5.5 \\
\text { dissolution } \\
\text { medium } \\
(200 \mathrm{ml})\end{array}$ & $99.73 \pm 0.52$ & $99.78 \pm 0.39$ & $101.03 \pm 0.57$ \\
\hline
\end{tabular}

Values reported as mean $\pm S D(n=3)$

\section{CONCLUSION}

The present study focused the importance of $\mathrm{pH}$ independent extended releases formulations with $\mathrm{pH}$ modulating agent, dissolution method for Dipyridamole was developed and validated according to $\mathrm{ICH}$ guidelines. Still tablet dosage form is not available in the market due to their $\mathrm{pH}$ dependent solubility. The use of $250 \mathrm{ml}$ of $\mathrm{pH} 5.5$ phosphate buffer as the dissolution medium at $37 \pm 0.5^{\circ} \mathrm{C}$ and $100 \mathrm{rpm}$ produced satisfactory results. This is the first time new method was developed for $\mathrm{pH}$ dependent soluble Dipyridamole. This kind of information may be useful in the proposal of official monographs for dissolution assays that resemble physiological conditions. The developed dissolution method will be helpful in formulation development of $\mathrm{pH}$ dependent soluble drugs and assessment of quality.

\section{ACKNOWLEDGMENT}

The authors would like to thank R-chem. PVT. LTD. Hyderabad, providing the gift sample of Dipyridamole. We gratefully acknowledge the Vikas college of Pharmacy at Vissannapeta for allowing access to the dissolution testing that is part of the research laboratory. This work has been taken from a part of Ph.D thesis undertaken under JNTU Kakinada.

\section{CONFLICT OF INTEREST}

The authors report no conflict of interest.

\section{ABBREVIATIONS}

ICH: International Conference on Harmonisation; USP: United States Pharmacopeia; $\mathbf{R} \mathbf{p m : ~ r e v o l u t i o n s ~ p e r ~ m i n - ~}$ ute; RSD: Relative Standard Deviation; $\mu \mathrm{g}:$ micro-gram; DIP: Dipyridamole; ${ }^{\circ} \mathrm{C}$ : Degree Centigrade; ML: Milli Liter.

\section{REFERENCES}

1. Strebel A, Siepmann J, Dashevsky A, Bodmeier R. pH-independent release of a weakly basic drug from water-insoluble and soluble matrix tablets. Journal of controlled release. 2000;67(1):101-10.

2. Dissoluton Testing of Immediate Release Solid Oral Dosage Forms; Guidance for Industry; US.Department of Health and Human Services, Food and Drug Administraton, Center for Drug Evaluaton andResearch (CDER) US. Government Printng Ofce: Washington DC. 1997.

3. Varma MV, Kaushal AM, Garg S. Influence of microenvironmental pH on the gel layer behavior and release of a basic drug from various hydrophilic matrices. Jounal of controlled release. 2005;103(2):499-510.

4. Chevalier E, Viana M, Artaud A, Chomete L, Haddouchi S, Devidts G, et al. Comparison of Three Dissoluton Apparatuses for Testng Calcium Phosphate Pellets used as Ibuprofen Delivery Systems. AAPS PharmSciTech. 2009;10(2):597-605. DOI: 10.1208/s12249-009-9252..

5. Emara LH, El-Menshawi BS, Estefan MY. In vitro-in vivo correlation and comparative bioavailability of vincamine in prolonged-release preparations. Drug Dev. Ind. Pharm. 2000;26(3):243-51.

6. Cell Designs on the Release of Diclofenac Sodium SR Tablets. Dissolution Technol. 2009;16(2):23-31.DOI:10.14227/DT160209P23.

7. Fotaki N, Aivaliots A, Butler J, Dressman J, Fischbach M, Hempenstall J, et al. A comparatve study of different release apparatus in generatng in vitroin vivo correlatons for extended release formulatons. Eur. J. Pharm. Biopharm. 2009;73(1):115-20. DOI:10.1016/j.ejpb.2009.04.012.

8. Hanafy A, Spahn-Langguth H, Vergnault G, Grenier P, Tubic Grozdanis M, Lenhardt, $\mathrm{T}$, et al. Pharmacokinetc evaluaton of oral fenofbrate nanosuspensions and SLN in comparison to conventonal suspensions of micronized drug. Adv. Drug Delivery Rev. 2007:59(6):419-26. DOI:10.1016/j. addr.2007.04.005

9. Law D, Wang W, Schmit EA, Qiu Y, Krill SL, Fort JJ. Propertes of rapidly dissolving eutectic mixtures of poly(ethylene glycol) and fenofbrate: The eutectc microstructure. J Pharm Sci. 2003;92(3):505-15.

10. Pharm J. Sc Sanghvi N. et al. Controlled drug delivery of $\mathrm{pH}$-dependent soluble drug Pindolol, Drug Dev. Ind.Pharm, 20, 111-118i. 2003;92(3):505-15. DOI: 10.1002/jps.10324.

11. Vogt M, Kunath K, Dressman JB. Dissoluton enhancement of fenofbrate by micronizaton,cogrinding and spray-drying: Comparison with commercial preparatons. Eur. J. Pharm.Biopharm. 2008;68(2):283-8. DOI: 10.1016/j. ejpb.2007.05.010.

12. Persson LC, Porter CJ, Charman WN, Bergström CA. Computatonal Predicton of Drug Solubility in Lipid Based Formulaton Excipients. Pharm. Res13. Higuchi T. Mechanism of sustained action medication: Theoreticalanalysis of rate of release of solid drugs dispersed in solid matrices. J Pharm Sci. 1963;52:1145-9.

13. Korsmeyer RW, Gurny R, Doelker E, Buri P, Peppas NA. Mechanism of solute release from porous hydrophilic polymers. Int J Pharma. 1983;15(1):25-35.

14. Bolourchian N, Dadashzadeh S. pH-independent release of propranolol hydrochloride from HPMC based matrices using organic acids, DARU Journal of Pharmaceutical Sciences, Vol. 16(3):136-142.

15. Jayanthi. $\mathrm{PH}$ independent controlled release swellable matrix tablets. International Journal of Research in Ayurveda and Pharmacy. 2011; 2(2):577-80.

16. Padhy KK. Influence of organic acids on drug release pattern of verapamil hydrochloride pellets, Journal of Advanced Pharmaceutical Research. 2010;1:65-73. 


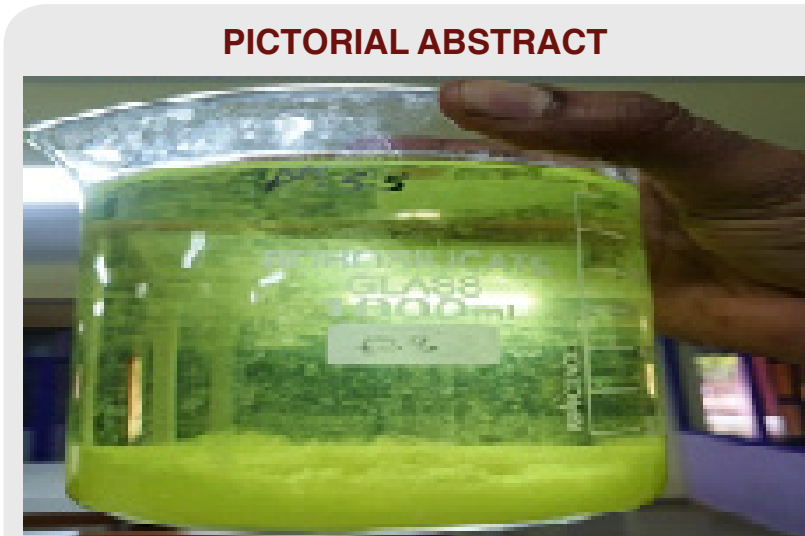

Precipitation of the drug in $\mathrm{pH} 5.5$ dissolution medium $(900 \mathrm{ml})$

\section{SUMMARY}

The compressed coated tablets, on dissolution study was performed in to individual $\mathrm{pH}$ mediums both $\mathrm{pH}$ 1.2 and 5.5 phosphate buffer, with controlled release up to $10 \mathrm{~h}$. The New dissolution method for Dipyridamole extended $\mathrm{pH}$ independent released tablets was developed and validated according to $\mathrm{ICH}$ guidelines. The use of $500 \mathrm{ml}$ of $\mathrm{pH} 5.5$ phosphate buffer as the dissolution medium at $37 \pm 0.5{ }^{\circ} \mathrm{C}$ and $100 \mathrm{rpm}$ produced satisfactory results. Dissolution testing of $\mathrm{pH}$ independent extended released tablets containing Dipyridamole with $\mathrm{pH}$ modulating agent (tartaric acid) resulted in different dissolution profiles, confirming the best dissolution method. The developed dissolution method will be helpful in formulation development of $\mathrm{pH}$ independed extended released Dipyridamole tablet dosage form and assessment of quality and performance of different batches.

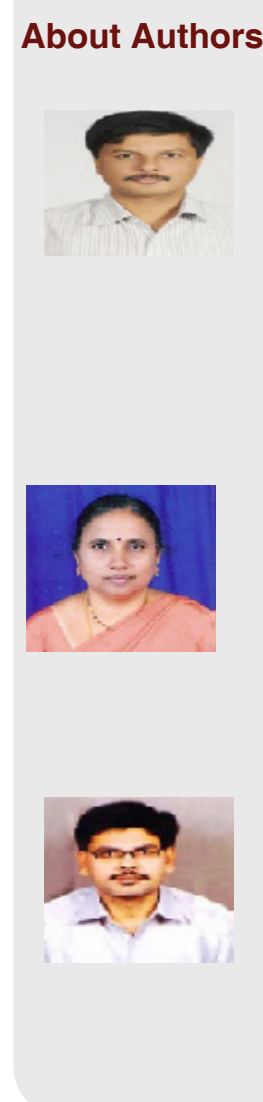

\section{About Authors}

Dr. T.E. Gopala Krishna Murthy: M. Pharm., Ph. D. Principal, Professor, Bapatla College of Pharmacy served as an academic supervisor to more than 60 Master Degree dissertations and 9 PhD Degree dissertations for the award of M.Pharm and PhD Degrees. He has published many research articles in reputed national and international Journals. He received fellowship from Association of Pharmacy and Biotechnology and is a recipient of meritorious teacher award from JNTUK, Kakinada. He is acting as Editorial Board Member for various journals, authored 4 text books and filed for 5 Patents. $\mathrm{He}$ acted as Convener for two AICTE Sponsored National Seminars and two Staff Development Programmes. He was granted generous funds from AICTE under RPS and MODROBS Schemes during his academic service till now

Dr. Prameela Rani Avula: Principal and Professor University College of Pharmaceutical Sciences Acharya Nagarjuna University Nagarjuna Nagar, Guntur. Carried out the research work under the guidance of Prof. K P R Chowdary, AU and was awarded the Ph.D from JNTU, Hyderabad in the year 2005. His is having 25 yrs of teaching includes 20yrs of Research Experience,Major research projects funded by UGC - 1 (11Lakhs sanctioned by UGC) AICTE - 1 (15 Lakhs sanctioned by AICTE) She has published many research articles in reputed national and international Journals. She has shared his research experience on the platforms of national and international conferences, workshops, seminars and symposia.

A.Anil kumar is an Associate Professor at the Department of Pharmaceutics, Vikas College of pharmacy, Vissannapeta. He is having $8.5 \mathrm{yrs}$ of teaching experience. His research interest is in the area of oral $\mathrm{pH}$ independent controlled drug delivery system, Floating, Mucoadhesive and herbal formulations. Currently perusing part time Ph.D. from JNTU, kakikinada, under the guidance of Dr. T.E. Gopala Krishna Murthy Professor and principal, Bapatla college of pharmacy, Bapatla and Dr.A. PRAMEELA RANI, Principal and Professor University College of Pharmaceutical Sciences Acharya Nagarjuna University Nagarjuna Nagar, and Guntur on topic: Oral pH independent controlled drug delivery system

Cite this article: Anilkumar A, Murthy TEGK, Rani AP. Development of ph Independent Drug Release System for Dipyridamole. Indian J of Pharmaceutical Education and Research. 2018;52(3):374-80. 